University for Business and Technology in Kosovo

UBT Knowledge Center

UBT International Conference

2012 UBT International Conference

Nov 2nd, 9:00 AM - Nov 3rd, 5:00 PM

\title{
Water resources systems planning and management
}

Piro Zoga

Polytechnic University of Tirana, pzoga@yahoo.com

Aida Bode

Polytechnic University of Tirana, boaal@yahoo.com

Ramiz Balla

Shoqëria Tirana, ramizballa@yahoo.com

Nevton Kodhelaj

Polytechnic University of Tirana, nevtonkodheli@yahoo.com

Spartak Kucaj

Polytechnic University of Tirana, spartaku_2005@yahoo.it

Follow this and additional works at: https://knowledgecenter.ubt-uni.net/conference

Part of the Computer Sciences Commons, and the Engineering Commons

\section{Recommended Citation}

Zoga, Piro; Bode, Aida; Balla, Ramiz; Kodhelaj, Nevton; and Kucaj, Spartak, "Water resources systems planning and management" (2012). UBT International Conference. 67.

https://knowledgecenter.ubt-uni.net/conference/2012/all-events/67

This Event is brought to you for free and open access by the Publication and Journals at UBT Knowledge Center. It has been accepted for inclusion in UBT International Conference by an authorized administrator of UBT Knowledge Center. For more information, please contact knowledge.center@ubt-uni.net. 


\title{
Water resources systems planning and management
}

\author{
Piro Zoga ${ }^{1}$, Aida Bode ${ }^{1}$, Ramiz Balla ${ }^{2}$, Nevton Kodhelaj ${ }^{3}$, Spartak Kuçaj ${ }^{1}$ \\ ${ }^{1}$ Department of Mineral Resources Engineering, Faculty of Geology and Mines, UPT, Tirana, Albania \\ ${ }^{2}$ Shoqëria Tirana, DKK, Tirana, Albania \\ Email: pzoga@albmail.com, aida.bode@fgim.edu.al, spartaku2005@yahoo.it, \\ Email: ramizballa@yahoo.com, \\ ${ }^{3}$ Department of Energy Resources, Faculty of Geology and Mines, UPT, Tirana, Albania \\ Email:nevtonkodheli@yahoo.com,
}

\begin{abstract}
The most fundamental human needs of water are for drinking, cooking and personal hygiene. In order to fulfill these needs, the quality of the water used should cause no risk to human health. The quality of the water in nature also affects the condition of ecosystems all living organisms depend on. At the same time, humans use water bodies as convenient sinks for the disposal of domestic, industrial and agricultural wastewaters. This, of course, degrades the quality of those water bodies. Water resources management involves the monitoring and management of water quality as much as the monitoring and management of water quantity.

Various models have been developed to assist in predicting the water quality impacts of alternative land and water management policies and practices.

This research provides a pricing framework for decision-makers that will help in the development of strategies for water quality management. However, trading schemes can be complex to set up with factors such as the number of facilities involved in the scheme and the variety of the pollutants discharged influencing the complexity. Success depends upon achieving a balance between the environmental benefits of improving water quality and administration costs.

In Europe the drive to improve water quality under the EU Water Framework Directive (WFD) encourages European citizens to get involved in improving water quality. Following recommendations from the IPCC3, the WFD aims to prevent and control emissions into water. Implementation of trading schemes could contribute to these goals.
\end{abstract}

Keywords: mathematical models, Tirana-Ishmi, basin, TDML, environmental protection, GIS.

\section{Introduction}

Importance of anthropogenic activities and the existing natural-geographic characteristic of the terrain indubitably make the web of factors bound together by cause-consequence relationships. Use of one sided approaches in solving problems of river's basin water quality have not brought satisfactory achievements (Bode A, Zoga P, 2009). Actual approaches to the problem of water quality in the world, especially those in the EU and the USA, are based upon application of integral analyses including all river basins (Piperski J, Salvai A, 2008). The European approach has been enacted by the Water Framework Directive (Council Directive, 2000/60/EC) integrating numerous previous directives. WFD contains a number of recommendations Member States should implement within their regulatory frameworks in order to achieve the goal - "good water quality" until 2015. These recommendations refer to water quality standards, and also limitations of effluent discharges. Alike to the mentioned framework, the Clear Water Act of the USA within the Section 303d is limiting effluent discharges by imposing defining Total Maximum Daily Load (TMDL) for each source of pollution. Achieving water quality standard in the USA has been accomplished by making integral plans for protection of rivers and stream that have been developed for each impaired river, or reach where water quality has been deteriorated. The plans obligatorily include developing TMDL. 
The large number of data that are necessary to be collected for integral analyses, as well as difficulties that might arise during data processing, assume more frequent application of adequate water quality models. In the developed countries that managed to control water pollution, an important role has been po sed to application of appropriate water quality models. It brings an insight into processes in watersheds, and also makes easier assessing of relative contribution of each polluter. Benefits of GIS technologies and models application may also be seen for improving trans-boundary communication and information exchange, e.g. within the Water Observation and Information System for Balkan Countries (Keum Hwan Yoo, Heekyung P, 2007). Therefore, the aim of this paper is to point out possibility of water quality models application in conditions characterizing Ishmi's watershed in order to achieve "good quality" and sustainable use of water.

The territory of Albania is divided in six drainage basins amongst which the Erzeni-Ishmi basin is located in the center of Albania. It is composed of the catchment of the Erzeni and Ishmi rivers, which surface is $1439 \mathrm{~km} 2$. There are included some smaller catchments in this basin, like Erzeni-Sukthi and Durrës plains located in both sides of Erzeni river outfall. Consequently the Erzeni-Ishmi basin has a total surface of about $1850 \mathrm{~km}^{2}$. Tiranë-Ishëm basin is characterized from rich hydrographic network. Main River is Ishmi River with its effluents: Lana, Tirana, Tërkuza, Zeza and Gjola Rivers (Kabo M, et al. 1990-1991, Pano N, et al. 1985).

This basin area has the highest density population and it is the most industrialized area of Albania. The total population of the area is about 1100000 inhabitants. There are situated here two biggest cities of Albania, Tirana the capital with about 650837 inhabitants (INSTAT 2009), and Durrës with about 120000 inhabitants. Both cities, as well as all the area under study are experiencing fast and big demographic development (Bode A, 2012; Peza V, Bode A, 2011).

\section{Materials and methods}

\section{State of affairs of water quality in Tirana-Ishmi basin}

Growing up of Tirana City with high rhythms till to rural zones is causing surface water and ground water pollution. Overpopulation phenomenon has affected the quality of these waters too. It is proved from results of chemical analyses as shown in Table 1,2.

Sewage system of Tirana City is a combined system of sewage and rain waters. It is a self-pouring system, because there is no sewage pumping station except one in Kombinat zone. In the greatest part of network the sewage and rain waters flow in the same channels and at the vicinity of water flow, rain water overflows with sewage (Bode A, 2012).

There are six points of sewage discharge in the Lana River and four suchlike in Tirana River that means a certain density in a relatively short distance. Also there are two points in Zeza River.

With the exception of the main pipes, it must be emphasized that there are many pipes not drawn in the map of engineering network, because they are illegal. The rivers are the main resource of gravel layers. Consequently they are a potential risk for groundwater pollution. The "hot spots" that conduct the pollution in water-bearing layer are points where ground water is in direct contact with rivers. There are drawn in the map water-bearing gravel that is outcrop in the surface at Tirana, Tërkuza and Zeza rivers.

\section{Results}

We are based in "Criteria of environments quality" of Water Research Institute, Norway, (Bratli L.J, 2000, NIVA) and Europe Community Directive for natural water quality (EC Design: 78/659, d 18.07078 2000; BMZ, 1995; Cullaj A, at al. 2005) for the evaluation of river water quality.

Classification of water quality from the anthropogenic waste is shown in table 1,2 as per water quality class for every river, for all Ishmi basin (Bode A, 2012). 
Table 1: Classification according to NIVA

\begin{tabular}{|c|c|c|c|c|c|c|}
\hline Code & $\begin{array}{l}\text { Class } \\
\text { Ptotal }\end{array}$ & $\begin{array}{l}\text { Class } \\
\mathrm{NH}_{4}^{+} \\
\end{array}$ & $\begin{array}{l}\text { Class } \\
\text { DO }\end{array}$ & $\begin{array}{l}\text { Class } \\
\mathrm{pH}\end{array}$ & $\begin{array}{l}\text { Class } \\
\text { SS }\end{array}$ & $\begin{array}{c}\text { Class } \\
\text { Col } \\
\text { Fecale }\end{array}$ \\
\hline Lana & V & IV & III & I & $\mathrm{V}$ & $\mathrm{V}$ \\
\hline Tirana & IV & IV & III & I & V & V \\
\hline Ishmi & V & V & III & I & V & V \\
\hline Ishmi Basin & V & V & III & I & V & V \\
\hline
\end{tabular}

Table 2 : Classification according to UNECE

\begin{tabular}{|lllllll|}
\hline \multirow{2}{*}{ Code } & Class & Class & Class & Class & Class & Class \\
& Ptotal & $\mathrm{NO}_{3}$ & $\mathrm{BOD}_{5}$ & $\mathrm{COD}$ & $\mathrm{NH}_{4}{ }^{+}$ & $\mathrm{DO}$ \\
\hline \hline Lana & $\mathrm{V}$ & $\mathrm{I}$ & $\mathrm{V}$ & $\mathrm{V}$ & $\mathrm{V}$ & $\mathrm{III}$ \\
Tirana & $\mathrm{V}$ & $\mathrm{I}$ & $\mathrm{V}$ & $\mathrm{V}$ & $\mathrm{IV}$ & $\mathrm{III}$ \\
Ishmi & $\mathrm{V}$ & $\mathrm{I}$ & $\mathrm{V}$ & $\mathrm{V}$ & $\mathrm{V}$ & $\mathrm{III}$ \\
Ishmi Basin & $\mathrm{V}$ & $\mathrm{I}$ & $\mathrm{V}$ & $\mathrm{V}$ & $\mathrm{V}$ & $\mathrm{III}$ \\
\hline
\end{tabular}

Based on the monitoring results (year 2010), parameters like COD, $\mathrm{BOD}_{5}, \mathrm{pH}$, are occasionally in III-IV-V class (according to the UNECE and NIVA classification). Suspended solids in all results are in V class or out of all categories. During 2010 it was registered concentration of total phosphorus in IV/V class, concentration of ammonium are in IV/V Class occasionally in II/I class and concentration of nitrates are on all of monitoring station in I class. Bacteriological monitoring indicated considerable increase of Coli form Fecal pollution (V class) (Bode $\mathrm{A}, 2012$ ). Status of surface water quality in Tirane- Ishmi basin for 9 monitoring station is shown on Figure 1.

Problems related to the monitoring are also worth mentioning like: not regular monitoring, caused by financial deficit, inaccessible sampling point, insufficient number of sampling points, etc. In such circumstances obtained assessments, as well as predictions of stream water quality are often not of satisfactory level of reliability (Piperski J, Salvai A, 2008).

\section{Discussion}

\subsection{Integral approach and water quality modeling}

Numerous problems, previously mentioned, concerning water quality in Tirana-Ishmi basin do not represent an exception in worldwide framework, but rather usual state of affairs in developed countries, and also in developing countries. Countries that have tradition of developing regulations within the field of environmental protection and problems of conservation and improvement of surface water quality have developed comprehensive approaches, resulting in up to date integral approaches that beside multidisciplinary view, require making decisions for whole watersheds (Bode A, 2012, Peza V, Bode A, 2011).

For surface waters the EU WFD requires "good quality" i.e. low level of changes as a result of human activities until 2015. Good status has been defined by biological elements of quality (e.g. phytoplankton, macrophytae and fish fauna), hydro-meteorological quality elements (e.g. hydrological regime, mud quantity), and physical-chemical quality elements (e.g. $\mathrm{pH}$, concentrations of oxygen, nutrients, and pollutants) including integral approach in assessments. Implementation of WFD includes analysis of current water quality status and impacts of human activities to the quality (until 2024), developing water management planning (until 2009), and application of proposed measures (until 2012). According to WFD for 2008 a draft plan for river management was planned (WFD: Timetable for implementation).

In case of the USA Environmental Protection Agency has conducted implementation of the Clear Water Act enforced in 1972 that announced new strategy of assessing Total Maximum Daily Loads - TMDLs. TMDL represents assessment of maximal daily amount of polluting substances of the polluter that water body can receive without disturbing water quality standards. Martin and Kennedy (2000) describe a TMDL as "a process as well as an endpoint". The process includes first identifying the water bodies that are impaired, establishing priorities, and then determining and implementing a TMDL that will remove that impairment or threat it. 
Mentioned complex approach requires development of abiotic and biotic models that could be used for processing numerous data and for establishing cause-consequence relationships among various factors. Therefore, modern approaches for assessment of different factors in environment, and water resources are based on application of water quality models (UNESCO 2005). According to WFD and TMDL concept hydrological models, as well as watershed water quality models, have role as additional tools in making decisions about rivers and watersheds. Numerous computer programs simulate scenarios for different hydrological systems and sizes of water tables. Especially, attention has been paid to parameters of polluters, water regime characteristics of streams, and their auto purifying ability.

Positive experiences during implementation of various models into regulatory frameworks contributed to more precise defining limits for discharging certain loads of polluting substances. Therefore, water quality models have been used by a significant number of environmental agencies worldwide. Literature published on the issue of water quality models in recent years clearly indicates that it has been an active field of research wo rldwide. One of the biggest users in Europe is Environmental Agency in England and Wales that used to apply water quality models for designing of all programs during past ten years. Models, used most often as regularly tools, but also as useful means for research and water quality simulations are: RQP, SIMCAT, TOMCAT, ISIS, MIKE, and QUASAR (Cox, 2003). In the USA within EPA a special center has been established: Watershed and Water Quality Modeling Technical Support Center (W\&WQMTSC). It has been involved in developing programs and in testing new regulations, thus representing a bridge between those involved in writing regulations and in their application. In that manner regulations written are based on real problems of environmental protection, and on the other hand, it enables their realistic application. Most of them have been improved in order to satisfy needs of TMDL program. GIS programs like BASINS and WCS provide necessary data for modeling of river watersheds, for predicting runoffs, and pollution from watershed. As stressed by Jobson (1997) programs in the system of modeling could be sorted into five levels: programs that generate time series of meteorological data (EQULTMP, SOLAR); time series data processing programs (INTRP, MRG); programs that build input files for transport models (BBLTM, QUAL2E); models with defined kinetic reactions (BLTM, QUAL2E), and finally plotting programs (CTPLT, CXPLT).

\subsection{Review of Concept of Total Maximum Daily Load}

Plan of sustainable water quality management enables broader view on water resources and reflects interactions among surface waters, underground waters, water quality and management of soil (United States Environmental Protection Agency-USEPA, 2009). The concept of TMDL includes plans for revitalization of water bodies (streams, rivers, lakes and estuaries) in order to provide good water quality. It involves following elements:

- Description of location, amount, sources of pollution in particular water body or stream segment;

- Assessment of amount of pollution that has to be deceased, or eliminated in order to maintain required water quality, and

- Control strategy and assessment of effectiveness. The TMDL concept represents crucial aspect based upon water quality and watershed management.

Implementation of TMDL is a process during which each discrete TMDL's will be developed. Following steps are identified as process for developing TMDL:

- Problem identification

- Analysis of goals

- Identification of sources and assessment

- Linking sources with goals

- Pollution load locating

- Implementing and developing monitoring plan

- Defining TMDL.

USA regulatory framework requires revision of the list of impaired streams every two years, for defining TMDL values. Purpose of TMDL implementation for water bodies, where water quality is being impaired, is to achieve water quality standards. In order to satisfy mentioned purpose, attention should be paid to allocation of permitted loads of pollution coming from different sources. TMDL may vary depending on season, or characteristics of specific location, and also of pollution load allocation.

Therefore, it is necessary to determine critical conditions for exact water body and the period for which TMDL has been developed, or even more TMDL values. At the end, proper mechanisms of control should be established and modified for achieving water quality standards.

Involvement of local communities has to play an important role in developing these plans, as well as during process of their implementation. With the support of experts, local community has to be involved in development of 
TMDL plans. Strategies of the mentioned plans might include effluent limitation for municipal or industry waste waters discharges, or suggesting the best management practice, e.g. planting trees and protective corridors composed of vegetative along streams banks.

\subsection{Advantages of water quality models application}

Water quality models contribute in a great deal to the integral overview of processes and changes of water quality in rivers and canals. They represent supplementary, but recently more often even basic tool for analysis of monitoring data, as well as for completing data if some are missing. The application of water quality models for prediction purposes has a distinctive importance. Advantages of water quality models might be listed as:

- Integral approach (incorporating and processing data from different scientific branches);

- Simulation of possible scenarios;

- Defining relative contribution for each pollution source, enabling more economical solutions;

- Especially useful tool for defining charge for polluters;

- Completing monitoring data (practical aspect);

- Help in accident situations (e.g. floods, accidental discharges, or low stream flows);

- Defining auto purification ability of water bodies (ecological aspect);

- Defining necessary stream flows that could enable dilution of pollutants, in order to preserve required water quality.

Figure 1:Status of surface water quality in Tirana -Ishmi basin

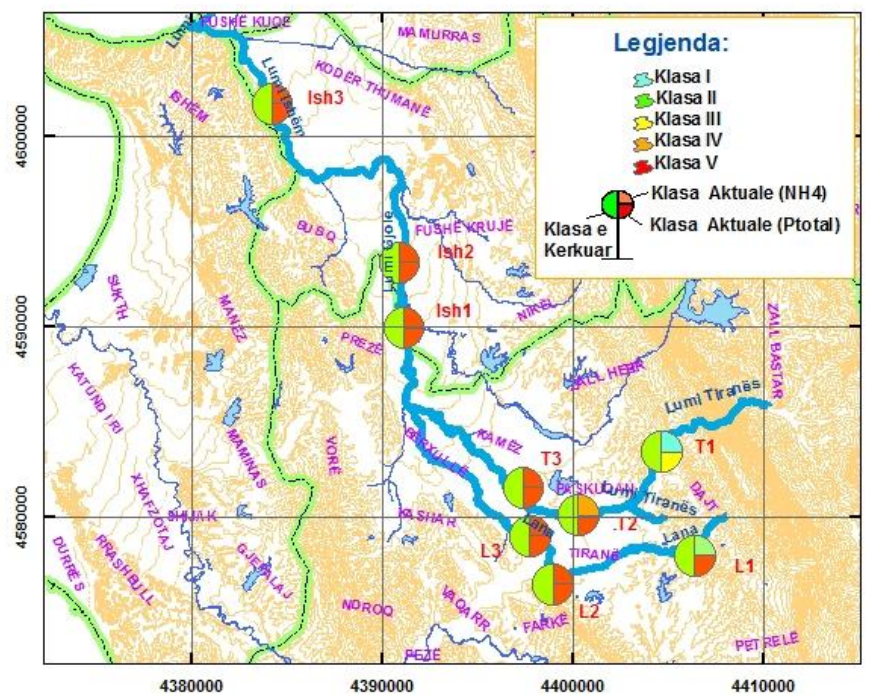

Beside numerous benefits water quality models offer, there are certain difficulties that arise during their application. At the first place, choice of the model could be a problem, because it has to be the most appropriate for the chosen conditions. Cox (2003) is recommending models of medium complexity for low land rivers, because they offer the best framework where dissolved oxygen can be investigated. Complex models like MIKE-11 and QUAL2E should be considered, because they include a large number of processes that could research not only oxy gen, but also other chemical properties of water. Attention has to be paid that complexity of any model must be consistent to quality and quantity of available data. Additionally, financial cost of models has to be considered

Application of the existing regulations does not bring precise insight into intensity of changing conditions of water quality in canals and rivers. Moreover, there is a problem of imprecision defining of relative load for separate polluters. Classification of water quality classifies all water bodies into IV/V class concerning water quality. However, the regulation does not refer to the water quality that should be achieved (e.g. WFD requires obtaining "good water quality", the goal is water quality of natural habitats of the ecoregion). For the Tirana- Ishmi basin required water quality would be at II class that supports life of cyprinid fishes, typical inhabitants of lowland rivers. There is a limitation of discharging effluents of dangerous substances concerning recipient's water quality, but it is not related to in stream conditions (hydrological, ecological, etc.). 


\section{Conclusion}

With respect to the fact that our country will face harmonization with the EU laws, changes towards implementation of new organizational patterns are inevitable. These changes should contribute to better monitoring and assessment of status of the environment, as well as more efficient management of water resources, and prediction of possible scenarios. GIS technology coupled with application of various water quality models would represent irreplaceable tools, thus their application should be implemented within regulatory framework. Reliance upon water quality models is not strictly required by the EU regulations, but in a number of Member states, models have been used in order to facilitate requirements of WFD.

Systematic monitoring that has been conducted according to the Regulation on Ways and Minimal Number of Samplings for Quality of Waste Waters should be amended with obligatory defining TMDL values for each polluter. Considering the fact that there are only a small number of stations with good water quality in Tirana - Ishmi basin it is necessary to elaborate plan for improvement of water quality for entire Erzeni - Ishmi basin based upon defined TMDLs. Additionally, it is necessary to revise methodology of pricing policy for polluters. Application of GIS and hydrologic, hydraulic and water quality models, and other computer programs, in terms of sustainable development of agriculture and water management in Tirana, indubitably has advantages.

Water quality in the Tirana- Ishmi basin is not satisfactory since 9 monitoring stations are in III/IV or IV class, and some are even within V class, or are out of all classes. Although there is abundant regulation covering issues of water, present water quality status is a result of absence of its application, and also there is a need for its modernization and amending. Sole application of existing regulations would lead to certain improvements. Hence, in

order to achieve "good water quality" for Tirana - Ishmi basin it is necessary to complete strategy for revitalization of "black holes".

\section{References}

BMZ ed., (1995) Environmental Handbook: documentation on monitoring and evaluation impacts, Vol. I-III, Vieweg, Leverkusen.

Bode A, (2012) Environmental Impact of Anthropogenic waste in Tirana watershed. PhD thesis, Polytechnic University of Tirana. (in Albanian)

Bode A, Zoga P, (2009) Problems of the environmental impact in the estuary of Seman on the Adriatik sea, Buletini Nafta Shqiptare, Volumi 163, Nr3.(in Albanian)

Bratli L.J, (2000) Classification of the Environmental Quality of Freshwater in Norway: Hydrological and limnological aspects of lake monitoring. Heinonen et al. John Willey \&Sons Ltd.

Council Directive 2000/60/EC of 23 (October 2000) Establishing a framework for Community action in the field of water policy, Official Journal L 327/1, 22.12.2000., p.1-72.

Cullaj A, et. Al, (2005) Environmental state of some rivers of Albania Adriatik lowland.

Piperski J, Salvai A, (2008)Water Quality Models Application in Vojvodina's Canal Network, Serbia, BALWOIS- Ohrid.

Kabo M, ed, (1990-1991) Physical geography of Albania, Vol I \& II Albanian Academy of Science, Tirana.

Keum Hwan Yoo, Heekyung P, (2007)A Development of the Integrated Water Quality Management System using GIS for a Small Watershed,Korea Advanced Institute of Science and Technology (KAIST), Korea

Pano, N, et al., (1985) Hydrology of Albania, Albanian Academy of Science, Tirana

Peza V, Bode A, (2011) Summary of findings for environment transparency of Tirana city, Vol II pg.717, XIV BMPC Balkan Mineral Processing Congress- Tuzla- Bosnia \& Herzegovina-June 14-17, ISBN 978-9958-31-038-6;

United States Environmental Protection Agency- [USEPA] (2009). Protocol for developing nutrient TMDL's. EPA 841-B-99-007. Office of Water (4503F) United States Environmental Protection Agency, Washington, DC. $135 \mathrm{pp}$.

W\&WQMTSC, Watershed \& Water Quality Modeling Technical Support Center Website,

http://www.epa.gov/athens/wwqtsc/index.html, Retrieved: 8th of February, 2008.

WFD: Timetable for implementation,

http://ec.europa.eu/environment/water/waterframework/info/timetable_en.htm, Retrieved: 4th of February, 2008

(C) UNESCO (2005), Water Quality Modeling and Prediction, Water resources systems planning and management - ISBN 92-3-103998-9 